\title{
Effects of no-till and rice varieties on nitrogen and phosphorus balance in rice fields
}

\author{
Jiao Yang ${ }^{1}$, Xinqiang Liang ${ }^{1,2^{*}} \mathbb{B}$, Hua Li $^{3}$, Yanfeng Chen ${ }^{1}$ and Guangming Tian ${ }^{1}$
}

\begin{abstract}
Background: Nutrient balance in rice paddy fields can change under different tillage management practices; however, the extent of the change may differ for various rice varieties. A field experiment was conducted over 2 successive years to clarify the effects of no-till and rice varieties on the apparent balance of nitrogen $(\mathrm{N})$ and phosphorus $(\mathrm{P})$. Four treatments: no-till/japonica rice (NTJ), no-till/glutinous rice (NTG), conventional tillage/japonica rice (CTJ), and conventional tillage/glutinous rice (CTG) with three replicates of each were established to test the hypothesis that no-till and japonica rice can improve the apparent balance of nutrients.

Results: The tillage method and rice variety had interactive effects on the apparent balance of N and P. After the 2-year experiment, total $\mathrm{N}$ and $\mathrm{P}$ pools in the $20 \mathrm{~cm}$ surface soil layer were highest under the NTJ treatment $\left(4757.0 \mathrm{~kg} \mathrm{~N} \mathrm{ha}^{-1}, 2428.5 \mathrm{~kg} \mathrm{P} \mathrm{ha}^{-1}\right)$ and lowest under the CTG treatments (4726.3 kg N ha ${ }^{-1}, 2412.0 \mathrm{~kg} \mathrm{P} \mathrm{ha}^{-1}$ ). Under no-till conditions, japonica rice had higher grain yield but lower straw biomass than that of glutinous rice. NTG treatment significantly increased the $\mathrm{N}$ and $\mathrm{P}$ content in rice grains and straw. The environmental losses of $\mathrm{N}$ and $\mathrm{P}$ in the rice fields mainly occurred during the rice season. Based on nutrient balance estimation, N losses in the NTJ, NTG, and CTJ treatments were reduced by $15.03 \mathrm{~kg} \mathrm{~N} \mathrm{ha}^{-1}, 11.55 \mathrm{~kg} \mathrm{~N} \mathrm{ha}^{-1}, 6.72 \mathrm{~kg} \mathrm{~N} \mathrm{ha}^{-1}$, respectively, as compared with that of the CTG treatment. The corresponding P losses were reduced by $8.02 \mathrm{~kg} \mathrm{P} \mathrm{ha}^{-1}, 7.84 \mathrm{~kg} \mathrm{P} \mathrm{ha}^{-1}$, and $3.96 \mathrm{~kg} \mathrm{Pha}^{-1}$. In terms of economic benefits, NTJ also resulted in the highest actual income (2724.25 US dollars) and the highest ratio of production investment (6.40).

Conclusion: No-till was more likely to maintain soil $\mathrm{N}$ and $\mathrm{P}$ nutrients than conventional tillage, and this advantage was most significant when planting japonica rice. In addition, no-till was conducive to $\mathrm{N}$ and $\mathrm{P}$ uptake by rice, but only japonica rice exhibited increased grain yield. Consequently, the NTJ treatment was recommended to improve the $\mathrm{N}$ and $\mathrm{P}$ balance.
\end{abstract}

Keywords: No-till, Conventional tillage, Rice varieties, Rice fields, Nitrogen, Phosphorus

\section{Background}

The adoption of the no-till agricultural method has occurred for over approximately 125 million hectares worldwide, which is equivalent to $9 \%$ of the global arable land [1]. Compared with conventional tillage, no-till

\footnotetext{
${ }^{*}$ Correspondence: liang410@zju.edu.cn

${ }^{1}$ College of Environmental and Resource Sciences, Zhejiang University, Hangzhou 310058, China

Full list of author information is available at the end of the article
}

(a method of direct planting crops with minimizing soil disturbance) can reduce soil erosion [2], improve soil aggregation ability $[3,4]$, retain soil moisture $[3,5]$, and improve soil structure $[2,6]$. Consequently, it can also increase crop yields, reduce economic inputs to the agricultural production systems [7], and achieve significant ecological benefits $[3,8]$. However, its applicability in different farming contexts is highly debated. Some studies have demonstrated that no-till only increased the nutrient content of the soil in the top $5 \mathrm{~cm}$ layer $[9,10]$. 
Nutrients availability may be decreased under no-till practices because of the absence or reduction of soil mixing. The surface application of fertilizer and straw mulching under long-term no-till practices may lead to nutrient layering [11, 12], and may not ensure an increase in crop yield [13]. In addition, no-till will cause ammonia volatilization in fertilizers, reduce the fixation of phosphorus (P) in the soil, and trigger the loss of fertilizer via runoff [3], thereby lowering the utilization efficiency of the fertilizer. Therefore, it is necessary to explore whether no-till is beneficial and can improve the nutrient balance, as well as crop yield.

Knowledge of the nitrogen $(\mathrm{N})$ and $\mathrm{P}$ balance (fertilizer inputs - crop uptake and harvest removal) is very important to understanding nutrient cycling in an agricultural production system [14-16]. Negative N and P balance (input < output) in the system will reduce soil fertility and crop yield, while a surplus of $\mathrm{N}$ and $\mathrm{P}$ (input $>$ output) in the system may increase the risk of $\mathrm{N}$ and $\mathrm{P}$ losses [1517]. Rice is an important staple food for more than half of the global population [18]. Numerous studies have been conducted on the effects of different rice varieties on the uptake and utilization efficiency of $\mathrm{N}$ and $\mathrm{P}$, and studies have shown that the $\mathrm{N}$ and $\mathrm{P}$ uptake characteristics are different under various varieties [19-21]. Generally, for varieties with high $\mathrm{N}$ and $\mathrm{P}$ utilization, the rice seasonal nutrient consumption is relatively large and less residual nutrients are left in the soil at the end of the rice season [22]. Because the variety of rice affects the uptake of $\mathrm{N}$ and $P[20,21]$, it can be inferred that rice varieties may affect the $\mathrm{N}$ and $\mathrm{P}$ balance in paddy fields. However, to date, there is a lack of information on the effects of rice varieties combined with that of tillage methods on nutrient balance.

In this study, we investigated the apparent balance of $\mathrm{N}$ and $\mathrm{P}$ under different tillage methods and rice varieties by measuring $\mathrm{N}$ and $\mathrm{P}$ concentrations in soil, rice grains, and straw. In addition, the yield and economic benefit from different treatments were also determined. The main objectives of this study were to check the effect of rice varieties in relation with different tillage practices (no-till and conventional tillage) on $\mathrm{N}$ and $\mathrm{P}$ apparent balance.

\section{Materials and methods}

\section{Site characterization}

The site that this research focused was situated in Jingshan Town, Yuhang District, Hangzhou City, Zhejiang Province, at $30^{\circ} 24^{\prime} \mathrm{N}, 120^{\circ} 6^{\prime} \mathrm{E}$. The site has a subtropical monsoon climate, and the annual rainfall is $1440 \mathrm{~mm}$. The physical and chemical properties of the topsoil layer $(0-20 \mathrm{~cm})$ of the rice field before the experiment are shown in Table 1.

\section{Experimental design}

The field experiment was conducted at over 2 successive years. We divided the 2-year experiment into four parts: the first rice season $\left(R_{1}\right.$, June 2016-October 2016), first fallow season $\left(F_{1}\right.$, October 2016-June 2017), second rice season ( $R_{2}$, June 2017-October 2017), and second fallow season $\left(F_{2}\right.$, October 2017-June 2018). The rice season and fallow season were combined into one planting season, which was defined as the first planting season $\left(T_{1}\right.$, June 2016-June 2017) and second planting season ( $T_{2}$, June 2017-June 2018). The two tillage methods (notill and conventional tillage) were assigned as the main plot factors, and the two rice varieties (japonica rice, Xiushui-134 and glutinous rice, Zhenuo-65) were the subplot factors. The experiments were established in a randomized complete block split-plot design with four treatments: no-till/japonica rice (NTJ), no-till/glutinous rice (NTG), tillage/japonica rice (CTJ), tillage/glutinous rice (CTG), with three replicates each. Each of the 12 plots had an area of $5 \mathrm{~m} \times 3 \mathrm{~m}$.

Each year, $90 \mathrm{~kg} \mathrm{ha}^{-1}$ of $\mathrm{K}_{2} \mathrm{O}, 100 \mathrm{~kg} \mathrm{ha}^{-1}$ of $\mathrm{P}_{2} \mathrm{O}_{5}$, and $250 \mathrm{~kg} \mathrm{~N} \mathrm{ha}^{-1}$ fertilizer were applied during the rice season, and the straw was returned to the field after the rice harvest. The irrigation method was wet and dry alternating irrigation [23]. The nylon membranes were used to coat ridges to reduce lateral seepage between adjacent plots.

\section{Soil sampling and analyses}

Parallel soil samples were taken from three points in each plot. All soil samples were air dried, ground, and sieved through a $100-$ mesh screen. Then the soil samples were used for the determination of basic physical and chemical properties. Before rice harvest, $1 \mathrm{~m}^{2}$ of rice plants

Table 1 Chemical and physical properties of the initial paddy soil in the experimental sites

\begin{tabular}{|c|c|c|c|c|c|c|c|c|c|}
\hline \multirow[t]{3}{*}{ Land use } & \multirow[t]{3}{*}{$\mathrm{pH}$} & \multirow[t]{2}{*}{ Total P } & \multirow[t]{2}{*}{ Total C } & \multirow[t]{2}{*}{ Total N } & \multirow[t]{2}{*}{ CEC } & \multirow[t]{2}{*}{$\rho b$} & \multicolumn{3}{|c|}{ Soil texture } \\
\hline & & & & & & & Sand & Silt & Clay \\
\hline & & $\mathrm{g} \mathrm{kg}^{-1}$ & & & $\mathrm{cmol} \mathrm{kg}^{-1}$ & $\mathrm{~g} \mathrm{~cm}^{-3}$ & $\%$ & & \\
\hline Paddy field & 6.17 & 0.98 & 17.21 & 1.89 & 13.5 & 1.215 & 9.0 & 59.3 & 31.7 \\
\hline
\end{tabular}

CEC indicate cation exchange capacity; $p$ b indicate soil bulk density 
were taken from each plot. After air-drying, the rice was threshed, and the straw and rice were crushed in a plant mill for testing.

The soil $\mathrm{pH}$ (soil/water ratio of 1:5) was measured using a glass electrode $\mathrm{pH}$ meter (PHS-3C, Shanghai). The bulk density of the soil was determined using the ring tool method. The determination of soil cation exchange capacity (CEC) was referred to the study of Liang et al. [24]. Soil texture was determined using the method recommended by the Chinese Soil Society (i.e., pipette method). Total $\mathrm{N}$ in the soil, grain, and straw were determined by elemental analyzer (Vario MAX CNS, Elementar, Germany). Soil total $\mathrm{P}$ was digested with an $\mathrm{H}_{2} \mathrm{SO}_{4}-\mathrm{HClO}_{4}$ solution [25], whereas rice and straw were digested with an $\mathrm{H}_{2} \mathrm{SO}_{4}-\mathrm{H}_{2} \mathrm{O}_{2}$ solution [26]. Both were evaluated using the molybdenum-blue colorimetric method. All reagents used were purchased from Sinopharm Chemical Reagent Co., Ltd.

\section{Data processing and analysis}

Soil $\mathrm{N}$ and $\mathrm{P}$ stock were calculated by soil bulk density and $\mathrm{N}$ and $\mathrm{P}$ concentrations in soil [27]:

$$
\begin{aligned}
B_{R(\mathrm{~N} / \mathrm{P})}= & \mathrm{N} / \mathrm{P} \text { content in the initial soil } \\
& +\mathrm{N} / \mathrm{P} \text { fertilizer }- \text { soil } \mathrm{N} / \mathrm{P} \text { stocks at } R_{\mathrm{E}} \\
& - \text { rice grain } N / P \text { content } \\
& - \text { rice straw } \mathrm{N} / \mathrm{P} \text { content. }
\end{aligned}
$$

$$
\begin{aligned}
B_{T(\mathrm{~N} / \mathrm{P})}= & \mathrm{N} / \mathrm{P} \text { content in the initial soil } \\
& +\mathrm{N} / \mathrm{P} \text { fertilizer }- \text { soil } \mathrm{N} / \mathrm{P} \text { stocks at } T_{\mathrm{E}} \\
& - \text { rice grain } \mathrm{N} / \mathrm{P} \text { content } \\
& - \text { rice straw } \mathrm{N} / \mathrm{P} \text { content. }
\end{aligned}
$$

$B_{R(\mathrm{~N} / \mathrm{P})}$ and $B_{T(\mathrm{~N} / \mathrm{P})}$ indicated the apparent balance of $\mathrm{N} / \mathrm{P}$ in the rice field during the rice season and planting season, respectively. $R_{\mathrm{E}}$ and $T_{\mathrm{E}}$ indicated the end of the rice season (October 2016 and October 2017) and the end of the planting season (June 2017 and June 2018) in this experiment, respectively.

Microsoft Excel 2016, and software Origin (version 8.0, OriginLab, USA) were used to plot and process the data. The effects of no-till/conventional tillage, japonica rice/glutinous rice, and their interactions on the $\mathrm{N}$ and $\mathrm{P}$ concentrations in soil, rice grain, straw, and yield analyzed by a two-way ANOVA with SPSS Statistics 20.0 (SPSS Inc. Chicago, USA).

\section{Results}

\section{Residual $\mathrm{N}$ and $\mathrm{P}$ in soils at the end of rice season}

In all the treatments, soil total $\mathrm{N}$ increased by the end of the 2-year experiments than that of the initial state $\left(1.89 \mathrm{~g} \mathrm{~kg}^{-1}\right)$. Planting japonica rice increased more soil

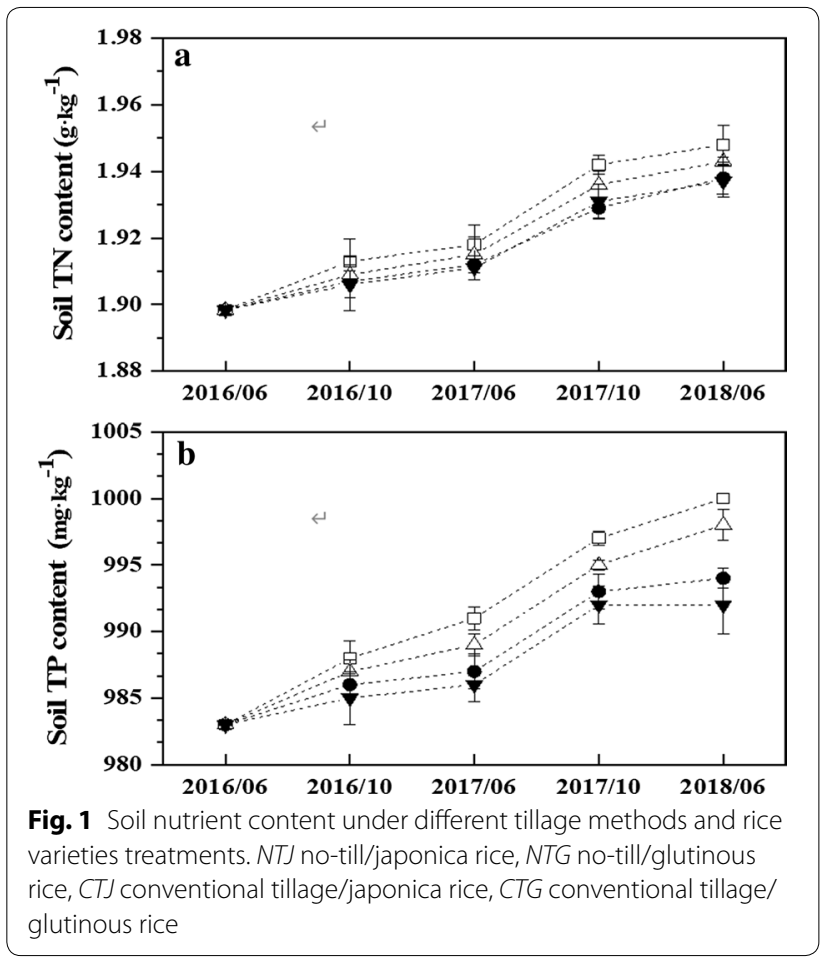

total $\mathrm{N}$ in the $0-20 \mathrm{~cm}$ layer (Fig. 1a). The improvement rates for total $\mathrm{N}$ under different treatment methods were as follows: NTJ (2.63\%), CTJ (2.37\%), NTG (2.11\%), and CTG (2.05\%). At the end of 2nd year, the total N content was the highest under the NTJ treatment $\left(1.95 \mathrm{~g} \mathrm{~kg}^{-1}\right)$, and lowest under the CTG treatment $\left(1.93 \mathrm{~g} \mathrm{~kg}^{-1}\right)$. Based on the increase in the soil total $\mathrm{N}$ content during the fallow season and the rice season, the means of total $\mathrm{N}$ content increased in fallow seasons $F_{1}$ and $F_{2}$ by $5.25 \mathrm{mg} \mathrm{kg}^{-1}$ and $7.00 \mathrm{mg} \mathrm{kg}^{-1}$ in the 2-year experimental period. The average increase in soil total $\mathrm{N}$ content of $R_{1}$ and $R_{2}$ was $10.80 \mathrm{mg} \mathrm{kg}^{-1}$ and $20.50 \mathrm{mg} \mathrm{kg}^{-1}$, respectively.

Compared with the total $\mathrm{P}$ content in the initial soil sample $\left(983 \mathrm{mg} \mathrm{kg}^{-1}\right)$, the total $\mathrm{P}$ content in the soil increased annually and japonica rice contributed to the increase (Fig. 1b). At the end of 2-years experiments, the improvement rates for total $\mathrm{P}$ of soil under different treatment methods were $1.73 \%, 1.53 \%, 1.12 \%$, and 0.92\% for NTJ, CTJ, NTG and CTG treatments, respectively. The total $\mathrm{P}$ content in the paddy soil was the highest $\left(1000 \mathrm{mg} \mathrm{kg}^{-1}\right)$ in the NTJ treatment and the lowest (992 $\mathrm{mg} \mathrm{kg}^{-1}$ ) in the CTG treatment. The average values of the total $\mathrm{P}$ content increase in $F_{1}$ and $F_{2}$ were $1.75 \mathrm{mg} \mathrm{kg}^{-1}$ and $1.80 \mathrm{mg} \mathrm{kg}^{-1}$, respectively. The average values of the soil total $\mathrm{P}$ content increases in $R_{1}$ and $R_{2}$ were $3.50 \mathrm{mg} \mathrm{kg}^{-1}$ and $6.00 \mathrm{mg} \mathrm{kg}{ }^{-1}$, respectively. This indicated that the increase in soil total $\mathrm{P}$ during the rice season was higher than that during the fallow season. 
Both no-till and the japonica rice variety contributed to the increase of residual $\mathrm{N}$ and $\mathrm{P}$ in the soils at the end of rice season, but the difference was not significant $(p>0.05)$ (Fig. 2a, b). The increase in soil $\mathrm{N}$ and $\mathrm{P}$ stocks during the rice season was significantly higher than that during the fallow season $(p<0.05)$. Compared with the initial $\mathrm{N}$ stocks in the rice field (4613.1 $\mathrm{kg} \mathrm{N} \mathrm{ha}^{-1}$ ), at the end of the experiments, the increase rate for the $\mathrm{N}$ pool in the rice field soil under the different treatments was: NTJ $(2.97 \%)>\mathrm{CTJ} \quad(2.48 \%)>\mathrm{NTG} \quad(2.45 \%)>\mathrm{CTG}$ $(2.22 \%)$. At the end of the two rice seasons $\left(R_{1 \mathrm{E}}\right.$ and $R_{2 \mathrm{E}}$ ), the increases in soil $\mathrm{N}$ stocks in the rice fields
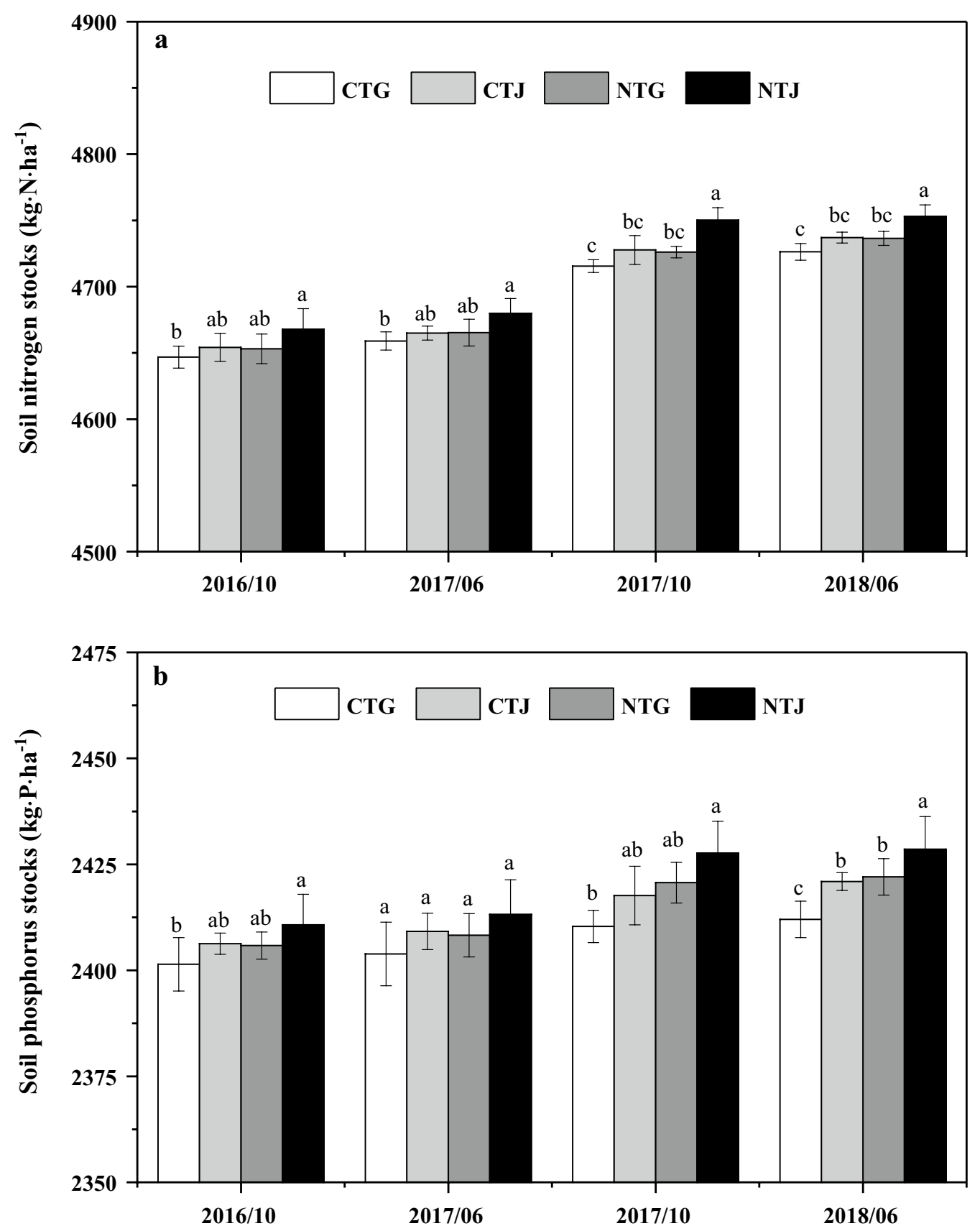

Fig. 2 Soil nutrient stocks under different tillage methods and rice varieties treatments. NTJ no-till/japonica rice, NTG no-till/glutinous rice, CTJ conventional tillage/japonica rice, CTG conventional tillage/glutinous rice. Different lowercase letters in each column indicate significant differences set at $p=0.05$ level 
were $42.34 \mathrm{~kg} \mathrm{~N} \mathrm{ha}^{-1}$ and $62.56 \mathrm{~kg} \mathrm{~N} \mathrm{ha}^{-1}$, respectively, and at the end of the two fallow seasons $\left(F_{1 \mathrm{E}}, F_{2 \mathrm{E}}\right)$ was $11.85 \mathrm{~kg} \mathrm{~N} \mathrm{ha}^{-1}$ and $9.35 \mathrm{~kg} \mathrm{~N} \mathrm{ha}^{-1}$, respectively.

Compared with the $\mathrm{P}$ stocks in initial rice fields soil (2400.6 $\mathrm{kg} \mathrm{P} \mathrm{ha}^{-1}$ ), at the end of 2-year experiment, the increase rate in $P$ stocks in the rice fields soil based on different treatments were: NTJ $(1.13 \%)>$ NTG $(0.84 \%)>$ CTJ $(0.71 \%)>$ CTG $(0.41 \%)$. At the end of the two rice seasons $\left(R_{1 \mathrm{E}}\right.$ and $\left.R_{2 \mathrm{E}}\right)$, the increase in soil P stocks in the rice fields was $5.44 \mathrm{~kg} \mathrm{P} h a^{-1}$ and $10.42 \mathrm{~kg} \mathrm{P} \mathrm{ha}^{-1}$, respectively, and at the end of the two fallow seasons $\left(F_{1 \mathrm{E}}, F_{2 \mathrm{E}}\right)$ was $2.56 \mathrm{~kg} \mathrm{P} \mathrm{ha}^{-1}$ and $1.81 \mathrm{~kg} \mathrm{P} \mathrm{ha}^{-1}$, respectively.

\section{Nutrient uptake by rice straw and grain}

The no-till treatment with glutinous rice did not have a significant effect on the total $\mathrm{N}$ content of the rice straw $(p>0.05)$, but it significantly increased the total P content in the rice straw and total $\mathrm{N}$ and total $\mathrm{P}$ content in rice grains $(p<0.05)$. In addition, the content of total $\mathrm{N}$ and total $\mathrm{P}$ in rice grains was much higher than that in rice straw $(p<0.05)$ (Table 2). During the 2-year experimental period, the change in total $\mathrm{N}$ content in rice straw and grain remained consistent under the different treatment conditions. The order of total $\mathrm{N}$ content in rice straw treated during different periods was NTG $\left(R_{1 \mathrm{E}}\right.$, $\left.8.20 \mathrm{~g} \mathrm{~kg}^{-1} ; R_{2 \mathrm{E}}, 8.31 \mathrm{~g} \mathrm{~kg}^{-1}\right)>\mathrm{CTG}\left(R_{1 \mathrm{E}}, 8.16 \mathrm{~g} \mathrm{~kg}^{-1} ; R_{2 \mathrm{E}}\right.$, $\left.8.27 \mathrm{~g} \mathrm{~kg}^{-1}\right)>\operatorname{NTJ}\left(R_{1 \mathrm{E}}, 8.11 \mathrm{~g} \mathrm{~kg}^{-1} ; R_{2 \mathrm{E}}, 8.21 \mathrm{~g} \mathrm{~kg}^{-1}\right)>\mathrm{CTJ}$ $\left(R_{1 \mathrm{E}}, 8.07 \mathrm{~g} \mathrm{~kg}^{-1} ; R_{2 \mathrm{E}}, 8.14 \mathrm{~g} \mathrm{~kg}^{-1}\right)$ (Table 2). The total $\mathrm{N}$ content of straw treated with NTG remained the highest
(8.20-8.31 $\left.\mathrm{g} \mathrm{kg}^{-1}\right)$. Compared with the CTJ treatment, the total $\mathrm{N}$ content of straw increased by $1.61-2.09 \%$. There was no significant difference in the total $\mathrm{N}$ content of rice straw under different tillage methods and rice varieties $(p>0.05)$. However, the total $\mathrm{N}$ content of the grains under NTG treatment increased by $6.79-9.77 \%$ than the CTJ treatment, which was significantly different $(p<0.05)$.

At $R_{\mathrm{E}}$, the order of total $\mathrm{P}$ content in rice straw under different treatment conditions was NTG $>\mathrm{NTJ}>\mathrm{CTG}>\mathrm{CTJ}$, whereas the order of total $\mathrm{P}$ content in rice grains was NTG $>$ CTG $>$ CTJ $>$ NTJ. The total P content of rice straw $\left(1.22-1.25 \mathrm{~g} \mathrm{~kg}^{-1}\right)$ and grains $\left(2.35-2.38 \mathrm{~g} \mathrm{~kg}^{-1}\right)$ under the NTG treatment remained the highest. The content of total P in rice straw (1.03-1.06 $\mathrm{g} \mathrm{kg}^{-1}$ ) under the CTJ treatment and that of rice grains $\left(2.11-2.15 \mathrm{~g} \mathrm{~kg}^{-1}\right)$ under the NTJ treatment were the lowest. Compared with CTJ, NTG significantly increased the total P content in rice straw by $17.92-18.45 \%$, and the total $\mathrm{P}$ content of rice grain treated with NTG was 10.70-11.37\% higher than that treated with NTJ, both of them showed a significant difference $(p<0.05)$.

The no-till and japonica rice treatment was beneficial to improving the $\mathrm{N}$ content of rice grains. In the 2-year experiment, $\mathrm{N}$ accumulation in rice grains showed an upward trend (Fig. 3a), and $\mathrm{P}$ accumulation in rice grains showed a similar trend (Fig. 3b). The $\mathrm{N}$ and $\mathrm{P}$ accumulation in the no-till rice fields were $2.23 \mathrm{~kg} \mathrm{~N} \mathrm{ha}^{-1}$ and $0.14 \mathrm{~kg} \mathrm{P} \mathrm{ha}^{-1}$ higher than those in the conventional

Table 2 Effect of tillage methods and rice varieties on nutrient content of rice tissues

\begin{tabular}{|c|c|c|c|c|c|}
\hline Rice tissues & Time & Treatment & $\begin{array}{l}\text { Total C } \\
\mathbf{g ~ k g}^{-1}\end{array}$ & Total N & Total P \\
\hline \multirow[t]{8}{*}{ Straw } & 2016.10 & NTJ & $376.84 \pm 3.18 b$ & $8.11 \pm 0.51 a$ & $1.10 \pm 0.28 b$ \\
\hline & & NTG & $384.85 \pm 1.44 a$ & $8.20 \pm 0.88 a$ & $1.22 \pm 0.35 a$ \\
\hline & & CTJ & $378.95 \pm 4.64 b$ & $8.07 \pm 0.02 a$ & $1.03 \pm 0.25 b$ \\
\hline & & CTG & $388.83 \pm 0.18 a$ & $8.16 \pm 0.40 a$ & $1.08 \pm 0.08 b$ \\
\hline & 2017.10 & NTJ & $386.51 \pm 0.84 c$ & $8.21 \pm 0.48 a$ & $1.12 \pm 0.26 a b$ \\
\hline & & NTG & $397.90 \pm 3.65 a$ & $8.31 \pm 0.67 a$ & $1.25 \pm 0.14 a$ \\
\hline & & CTJ & $391.07 \pm 0.62 b$ & $8.14 \pm 0.51 a$ & $1.06 \pm 0.09 b$ \\
\hline & & CTG & $402.11 \pm 2.43 a$ & $8.27 \pm 0.64 a$ & $1.10 \pm 0.36 a b$ \\
\hline \multirow[t]{8}{*}{ Grain } & 2016.10 & NTJ & $419.65 \pm 1.12 \mathrm{ab}$ & $12.25 \pm 0.84 b$ & $2.11 \pm 0.28 b$ \\
\hline & & NTG & $422.18 \pm 0.91 a$ & $13.06 \pm 0.22 \mathrm{a}$ & $2.35 \pm 0.12 \mathrm{a}$ \\
\hline & & CTJ & $418.25 \pm 0.47 b$ & $12.23 \pm 0.21 b$ & $2.19 \pm 0.10 b$ \\
\hline & & CTG & $420.03 \pm 0.72 a b$ & $12.54 \pm 0.02 \mathrm{ab}$ & $2.25 \pm 0.01 \mathrm{ab}$ \\
\hline & 2017.10 & NTJ & $420.80 \pm 1.93 a$ & $12.34 \pm 0.24 b$ & $2.15 \pm 0.02 b$ \\
\hline & & NTG & $423.71 \pm 1.48 a$ & $13.48 \pm 0.02 \mathrm{a}$ & $2.38 \pm 0.01 a$ \\
\hline & & CTJ & $418.85 \pm 1.47 a$ & $12.28 \pm 0.12 b$ & $2.21 \pm 0.01 b$ \\
\hline & & CTG & $421.76 \pm 1.39 a$ & $12.65 \pm 0.01 b$ & $2.28 \pm 0.03 a b$ \\
\hline
\end{tabular}



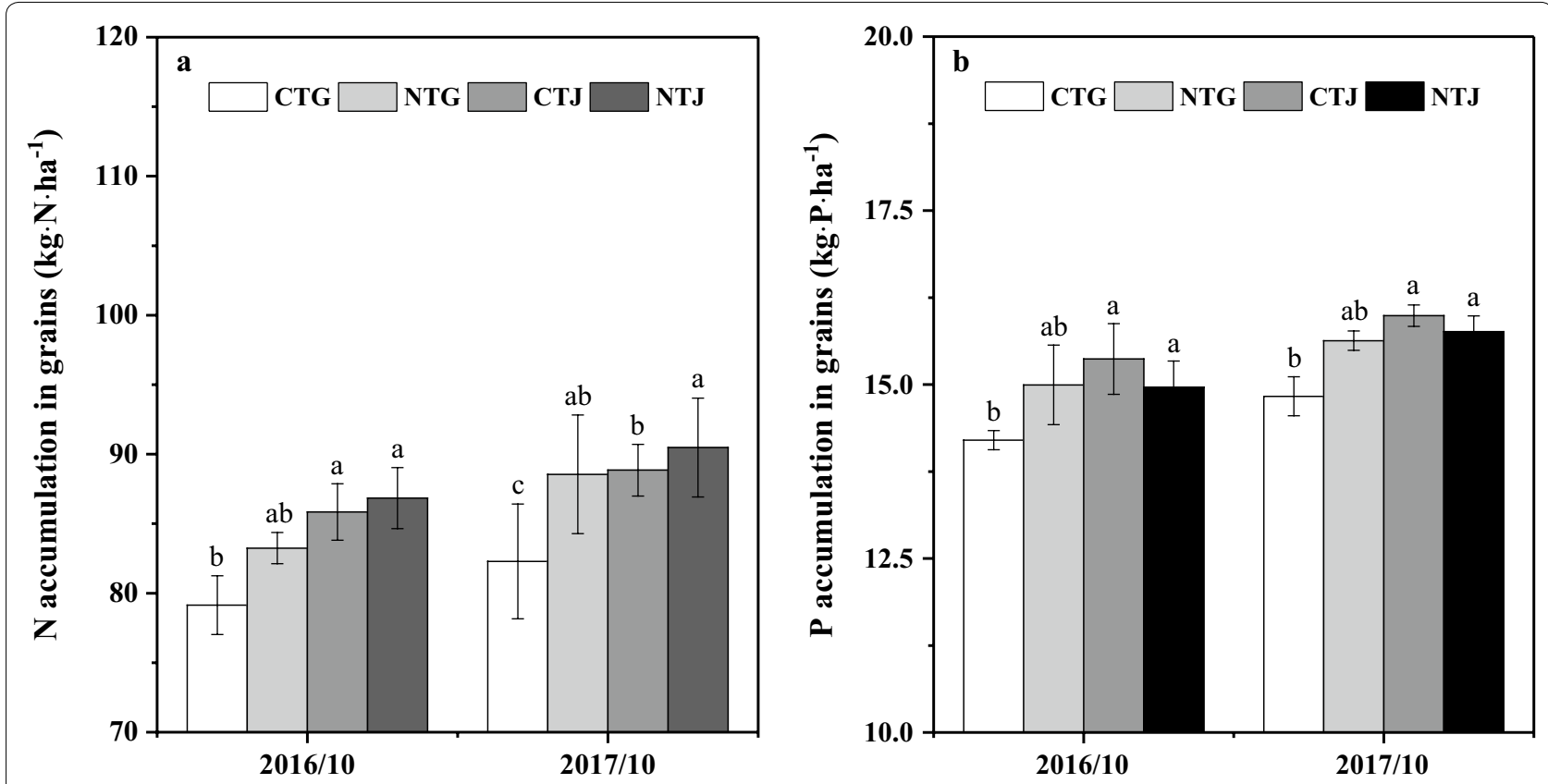

Fig. 3 Rice grain nutrient accumulation under different tillage methods and rice varieties treatments. NTJ no-till/japonica rice, NTG no-till/glutinous rice, CTJ conventional tillage/japonica rice, CTG conventional tillage/glutinous rice. Different lowercase letters in each column indicate significant differences set at $p=0.05$ level

tillage treatment, respectively. Japonica rice increased the $\mathrm{N}$ accumulation of the rice grains by $2.65 \mathrm{~kg} \mathrm{~N} \mathrm{ha}^{-1}$ and $\mathrm{P}$ accumulation by $0.37 \mathrm{~kg} \mathrm{P}^{-1}$, as compared with that of glutinous rice. Both of no-till and glutinous rice variety contributed to the increase in $\mathrm{P}$ accumulation in rice straw. At the end of the second rice season (October 2017), the $\mathrm{N}$ and $\mathrm{P}$ accumulation in rice straw showed an upward trend (Fig. 4a, b). The $\mathrm{N}$ and $\mathrm{P}$ accumulation in rice straw under the NTG treatment was the highest (70.30 $\mathrm{kg} \mathrm{N} \mathrm{ha}^{-1}, 10.58 \mathrm{~kg} \mathrm{P} \mathrm{ha}^{-1}$ ), and was $9.38 \%$ and $26.40 \%$ higher than that of CTJ treatment, respectively, all of which were significantly different $(p<0.05)$. In the 2-year experiment, the no-till treatment increased the $\mathrm{N}$ and $\mathrm{P}$ accumulation in rice straw by $1.02 \mathrm{~kg} \mathrm{~N} \mathrm{ha}^{-1}$ and $0.37 \mathrm{~kg} \mathrm{P} \mathrm{ha}^{-1}$, respectively, as compared with the conventional tillage treatment. The accumulation of $\mathrm{N}$ and $\mathrm{P}$ in rice straw in the glutinous rice treatment was $2.08 \mathrm{~kg} \mathrm{~N} \mathrm{ha}^{-1}$ and $0.53 \mathrm{~kg} \mathrm{P} \mathrm{ha}^{-1}$ higher than those of japonica rice.

There was a slight improvement in rice grain yield in the no-till treatment $(p>0.05)$; however, rice variety had a significant effect on the improvement of rice grain yield $(p<0.05)$. The grain yield of japonica rice was higher than that of glutinous rice. At the end of the two rice seasons, the grain yield of rice treated with the NTJ treatment was highest $\left(R_{1 \mathrm{E}}: 7090 \mathrm{~kg} \mathrm{ha}^{-1}\right.$;
$R_{2 \mathrm{E}}: 7332 \mathrm{~kg} \mathrm{ha}^{-1}$ ) (Table 3 ), and yield was increased by $11.23 \%\left(R_{1 \mathrm{E}}\right)$ and $11.62 \%\left(R_{2 \mathrm{E}}\right)$, as compared with that of the corresponding NTG treatment, respectively. The yield of grain in the CTJ treatment was the second and was $11.17 \%\left(R_{1 \mathrm{E}}\right)$ and $11.24 \%\left(R_{2 \mathrm{E}}\right)$ higher than that of the CTG treatment for the same period. However, the NTJ treatment only increased grain yield by $1.04-1.34 \%$ compared with that of the CTJ treatment, whereas the NTG treatment increased yield by only $1.00 \%$ compared with that of the CTG treatment. The no-till treatment improved the yield of rice straw $(0.26-1.69 \%)$, but the difference was not significant $(p>0.05)$. However, rice variety and the yield of rice straw were significantly correlated $(p<0.05)$. The yield of rice straw in the NTG treatment was always the highest $\left(8292-8360 \mathrm{~kg} \mathrm{ha}^{-1}\right)$ (Table 3$)$ and was $2.51 \%\left(R_{1 \mathrm{E}}\right)$ and $1.54 \%\left(R_{2 \mathrm{E}}\right)$ greater than the corresponding NTJ treatment. The yield of rice straw in the CTG treatment was the second highest, and a significant difference occurred between the CTG and CTJ treatments $(p<0.05)$. There was a greater yield of rice straw $\left(2.83 \%\left[R_{1 \mathrm{E}}\right]\right.$ and $\left.2.99 \%\left[R_{2 \mathrm{E}}\right]\right)$ under the CTG than CTJ treatment. The yield under the NTG treatment only increased by $0.03-0.89 \%$ compared with that of the CTG treatment, whereas the yield in the NTJ treatment increased by only $1.20-1.69 \%$ compared with that of the CTJ treatment. 

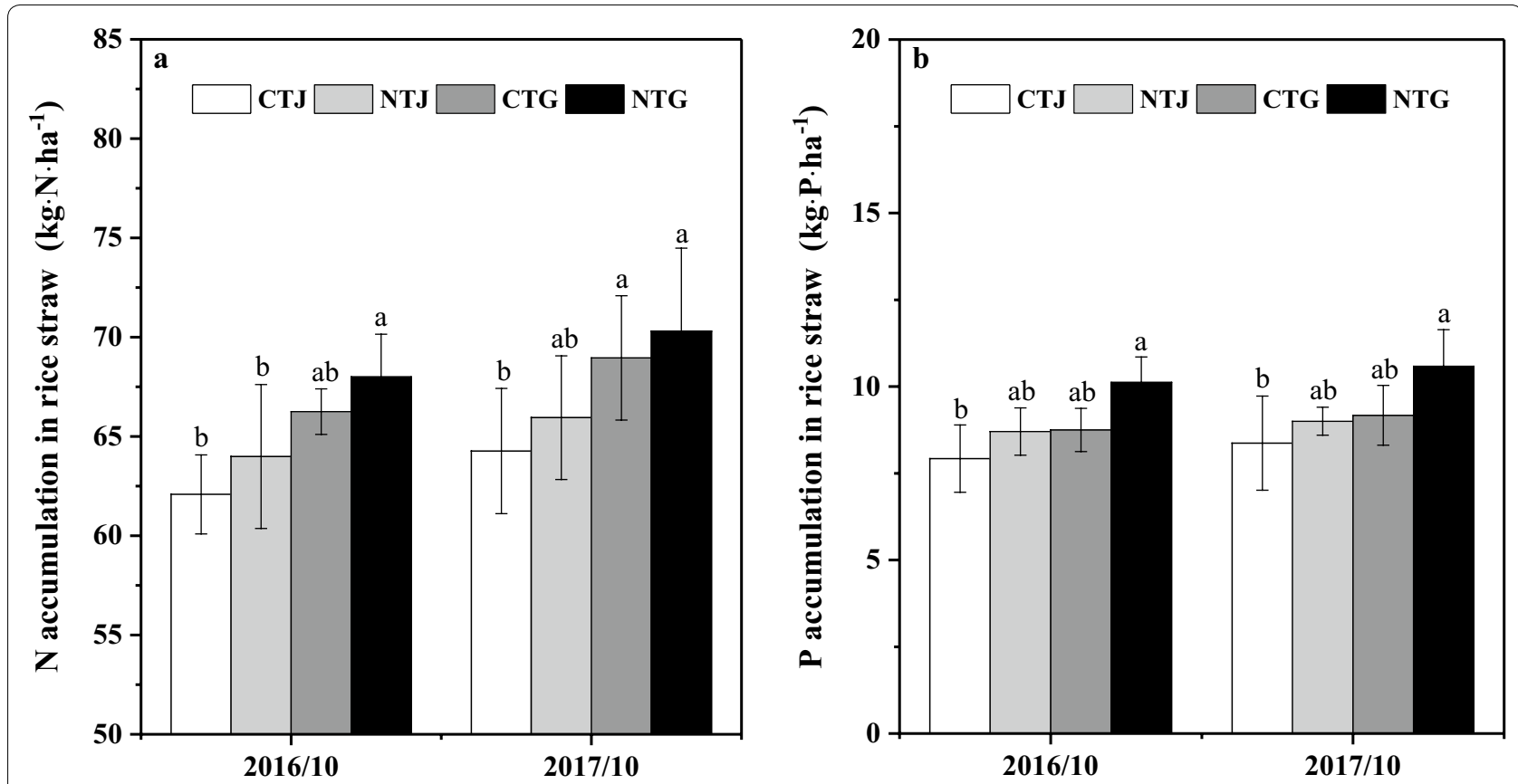

Fig. 4 Rice straw nutrient accumulation under different tillage methods and rice varieties treatments. NTJ no-till/japonica rice, NTG no-till/glutinous rice, CTJ conventional tillage/japonica rice, CTG conventional tillage/glutinous rice. Different lowercase letters in each column indicate significant differences set at $p=0.05$ level

Table 3 Effect of tillage methods and rice varieties on grain and straw yields

\begin{tabular}{llll}
\hline Time & Treatment & Grain yield $\left(\mathbf{k g ~ h a}{ }^{\mathbf{- 1}}\right)$ & Straw yield $\left(\mathbf{k g ~ h a}{ }^{-\mathbf{1}}\right)$ \\
\hline 2016.10 & NTJ & $7090 \pm 201 \mathrm{~b}$ & $8089 \pm 99 \mathrm{a}$ \\
& NTG & $6374 \pm 782 \mathrm{a}$ & $8292 \pm 74 \mathrm{~b}$ \\
& CTJ & $7017 \pm 205 \mathrm{~b}$ & $7993 \pm 150 \mathrm{a}$ \\
& CTG & $6312 \pm 113 \mathrm{a}$ & $8219 \pm 125 \mathrm{~b}$ \\
2017.10 & NTJ & $7332 \pm 207 \mathrm{~b}$ & $8233 \pm 100 \mathrm{~b}$ \\
& NTG & $6569 \pm 377 \mathrm{a}$ & $8360 \pm 46 \mathrm{c}$ \\
& CTJ & $7235 \pm 202 \mathrm{~b}$ & $8096 \pm 37 \mathrm{a}$ \\
& CTG & $6504 \pm 58 \mathrm{a}$ & $8338 \pm 54 \mathrm{c}$ \\
\hline
\end{tabular}

NTJ, NTG, CTJ, CTG indicate no-till/japonica rice, no-till/glutinous rice, conventional tillage/japonica rice, conventional tillage/glutinous rice, respectively. Different lowercase letters in each column indicate significant differences set at $p=0.05$ level

\section{Soil nutrient balance analysis}

By calculating the N/P balance in the rice fields during two consecutive seasons, it was found that no-till and japonica rice were conducive to improving the in situ reduction of $\mathrm{N}$ and $\mathrm{P}$ in the rice fields (Tables 4 and 5). The environmental loss of $\mathrm{N}$ and $\mathrm{P}$ during the planting season was lower than that during the rice season. Compared with the rice and planting seasons in the 1st year, the $\mathrm{N}$ and $\mathrm{P}$ environmental losses decreased during the rice and planting seasons in the 2 nd year.
The environmental losses of $\mathrm{N}$ and $\mathrm{P}$ in the rice fields mainly occurred during the rice season. At different time periods, the environmental losses of $\mathrm{N}$ and $\mathrm{P}$ in rice fields treated with CTG were the largest. After 2-year experiments, N losses in the NTJ, NTG, and CTJ treatments were reduced by $15.03 \mathrm{~kg} \mathrm{~N}^{-1}, 11.55 \mathrm{~kg} \mathrm{~N}$ $\mathrm{ha}^{-1}$, and $6.72 \mathrm{~kg} \mathrm{~N} \mathrm{ha}^{-1}$, respectively, as compared with that of the CTG treatment. The corresponding P losses were reduced by $8.02 \mathrm{~kg} \mathrm{P} \mathrm{ha}{ }^{-1}, 7.84 \mathrm{~kg} \mathrm{P} \mathrm{ha}^{-1}$, and $3.96 \mathrm{~kg} \mathrm{P} \mathrm{ha}^{-1}$.

\section{Economic benefits under different tillage methods and rice varieties}

From the perspective of economic benefits, the production cost of the no-till treatment was lower than that of conventional tillage method (Table 6). The no-till method saved 216.25 USD ha ${ }^{-1}$ for machine tillage and the same cost for fertilizer and rice seeds was assumed (the difference between the prices of the two rice seeds was negligible). The average price of japonica rice seeds (Xiushui-134) was approximately $380.60 \mathrm{USD}^{-1}$, and the average price of glutinous rice seeds (Zhenuo-65) was approximately $418.08 \mathrm{USD}^{-1}$. The NTJ treatment had the highest output-investment ratio (6.40), and the real income per hectare was 2724.25 USD. The NTJ treatment increased revenue by 293.22 USD (12.06\%) compared with that of the CTG treatment, 254.31 USD (10.30\%) 
compared with that of the CTJ treatment, and 45.74 USD (1.71\%) compared with that of the NTG treatment.

\section{Discussion}

Some controversies regarding the increase in yield with the no-till practice were reported, which may be related to planting conditions [28-31]. In our study, we found that the tillage methods had a non-significant effect on grain yield and straw biomass $(p>0.05)$, but rice variety had a significant effect on rice yield $(p<0.05)$, which is consistent with the results of Qin et al. [32]. We found that both the grain yield and the growth rate of grain under the NTJ practice were highest. Our results are supported by the finding of previous studies [7, 33, 34]. In terms of nutrient uptake, the no-till practice improved the physical and chemical properties of paddy soil and effectively maintained soil nutrients, which was consistent with the nutrient demand of rice [34]. On the other hand, tillage results in more uniform planting conditions (homogeneous planting depth, better soil-seed contact, etc.), which may have a positive impact on crop planting and yield. In addition, we cannot ignore the stratification of nutrients in NT, because lower concentrations at depth in the rooting zone may reduce crop yields [10]. Combined with these factors, no-till practice may be expected to have a non-significant positive effect on rice yields. Although the positive effect on the yield of rice under notill condition was not significant in our study, the practice was deemed successful at maintaining a comparable or higher rice yield, as well as nutrients in the rice soil under certain conditions.

Rice yield is closely related to factors such as grain number per panicle, 1000-grain weight, seed setting rate, and plant height $[33,35]$. The yield of rice grain for japonica rice was the highest among different treatments, while the biomass of straw grown with glutinous rice was the highest. These results may be varietal characters of the rice, indicating a close relationship between rice variety and yield. In addition, the nutrient uptake capacity of japonica rice was also higher, leading to the conclusion that the rice yield is related to the uptake of $\mathrm{N}$ and $\mathrm{P}$ by rice. This study showed that total $\mathrm{N}$ and total $\mathrm{P}$ in rice grains were higher than that in rice stalks, which indicated a greater availability of N, P, and other elements to the grains than rice straw. Under the NTG treatment, the content of total $\mathrm{N}$ and total $\mathrm{P}$ in rice straw and rice grains were the highest. The above results indicated that the accumulation of dry matter, $\mathrm{N}$, and $\mathrm{P}$ in rice was affected by rice variety and tillage conditions $[36,37]$.

Crop straw is rich in carbon, $\mathrm{N}, \mathrm{P}$, potassium, and other nutrients. Therefore, straw mulching is an important nutritional supplement, thereby increasing the uptake of nutrients by crops. In addition, returning straw can improve soil fertility, improve soil physical and chemical properties, and enhance microbial characteristics of the soil. As important technical measures in agricultural production, the combination of a no-till system and straw mulching not only improved soil water, fertilizer, and gas conditions [5, 38, 39], but also increased surface coverage and reduced surface runoff $[38,40,41]$. The comprehensive effects of management measures such as nutrients, water, and fertilizer were conducive to an increase in rice yield.

The no-till practice reduced the frequency of soil disturbance and caused less damage to the soil structure, which reduced the losses of soil $\mathrm{N}$ and $\mathrm{P}$ during erosion.

Table 4 Residues and apparent balance of nitrogen in paddy soil

\begin{tabular}{|c|c|c|c|c|c|c|c|c|c|}
\hline \multirow[t]{3}{*}{ Time } & \multirow{3}{*}{$\begin{array}{l}\text { Bulk density } \\
\mathrm{g} \mathrm{cm}^{-3}\end{array}$} & \multirow{2}{*}{$\begin{array}{l}\text { Soil } \\
\text { nitrogen } \\
\text { storage }\end{array}$} & \multirow{3}{*}{$\begin{array}{l}\text { Nitrogen } \\
\text { fertilizer }\end{array}$} & \multicolumn{3}{|c|}{ Nitrogen storage } & \multirow[t]{3}{*}{$\mathrm{B}_{\mathrm{RN}}$} & \multirow{3}{*}{$\begin{array}{l}\text { Soil } \\
\text { nitrogen } \\
\text { storage }\end{array}$} & \multirow[t]{3}{*}{$\mathrm{B}_{\mathrm{TN}}$} \\
\hline & & & & \multirow[t]{2}{*}{ Soil } & \multirow[t]{2}{*}{ Grain } & \multirow[t]{2}{*}{ Straw } & & & \\
\hline & & $\mathrm{kg} \mathrm{N} \mathrm{ha}^{-1}$ & & & & & & & \\
\hline \multicolumn{10}{|c|}{ 2016.06-2017.06 } \\
\hline NTJ & 1.215 & $4613.1 \pm 6$ & 250 & $4667.7 \pm 10 a$ & $86.84 \pm 2.1 a$ & $63.99 \pm 3.6 b$ & $44.54 \pm 5.1 b$ & $4679.9 \pm 8 a$ & $32.35 \pm 3 c$ \\
\hline NTG & & & & $4653.1 \pm 11 a b$ & $83.24 \pm 1.1 b$ & $67.99 \pm 2.1 \mathrm{a}$ & $58.78 \pm 4.2 \mathrm{a}$ & $4665.2 \pm 10 a b$ & $46.58 \pm 4 b$ \\
\hline CTJ & & & & $4654.1 \pm 10 a b$ & $85.84 \pm 2.0 \mathrm{ab}$ & $62.08 \pm 1.9 b$ & $61.04 \pm 5.7 \mathrm{a}$ & $4664.9 \pm 5 a b$ & $50.24 \pm 5 a b$ \\
\hline CTG & & & & $4646.8 \pm 8 b$ & $79.15 \pm 2.1 b$ & $66.25 \pm 1.1 \mathrm{ab}$ & $70.87 \pm 4.9 a$ & $4659.0 \pm 7 b$ & $58.68 \pm 6 a$ \\
\hline \multicolumn{10}{|c|}{ 2017.06-2018.06 } \\
\hline NTJ & 1.221 & $4679.9 \pm 8 a$ & 250 & $4750.1 \pm 9 a$ & $90.48 \pm 3.6 a$ & $65.95 \pm 3.1 \mathrm{ab}$ & $23.36 \pm 3.5 c$ & $4757.0 \pm 8 a$ & $16.48 \pm 1 c$ \\
\hline NTG & 1.222 & \multicolumn{2}{|c|}{$4665.2 \pm 10 a b$} & $4726.1 \pm 4 b c$ & $88.55 \pm 4.2 \mathrm{ab}$ & $70.30 \pm 4.1 \mathrm{a}$ & $30.38 \pm 4.4 b$ & $4736.5 \pm 5 b c$ & $19.96 \pm 2 b$ \\
\hline CTJ & 1.219 & \multicolumn{2}{|l|}{$4664.9 \pm 5 a b$} & $4727.7 \pm 10 b c$ & $88.85 \pm 1.8 b$ & $64.27 \pm 3.1 b$ & $34.11 \pm 3.8 a$ & $4737.0 \pm 4 b$ & $24.79 \pm 2 \mathrm{a}$ \\
\hline CTG & 1.220 & \multicolumn{2}{|l|}{$4659.0 \pm 7 b$} & $4715.5 \pm 10 c$ & $82.28 \pm 4.1 c$ & $68.96 \pm 3.3 \mathrm{a}$ & $42.29 \pm 7.9 a$ & $4726.3 \pm 6 c$ & $31.51 \pm 4 a$ \\
\hline
\end{tabular}

NTJ, NTG, CTJ, CTG indicate no-till/japonica rice, no-till/glutinous rice, conventional tillage/japonica rice, conventional tillage/glutinous rice, respectively. End of rice season: October 2016 and October 2017, end of winter fallow season: June 2017 and June 2018. $B_{\mathrm{RN}}$ : environmental loss of nitrogen in rice season; $B_{\mathrm{TN}}$ : annual environmental loss of nitrogen. Different lowercase letters in each column indicate significant differences set at $p=0.05$ level 
Table 5 Residues and apparent balance of phosphorus in paddy soil

\begin{tabular}{|c|c|c|c|c|c|c|c|c|c|}
\hline \multirow[t]{3}{*}{ Time } & \multirow{2}{*}{$\begin{array}{l}\text { Bulk } \\
\text { density }\end{array}$} & \multirow{2}{*}{$\begin{array}{l}\text { Soil phosphorus } \\
\text { storage }\end{array}$} & \multirow{2}{*}{$\begin{array}{l}\text { Phosphate } \\
\text { fertilizer }\end{array}$} & \multicolumn{3}{|c|}{ Phosphorus storage } & \multirow[t]{3}{*}{$B_{\mathrm{RP}}$} & \multirow{3}{*}{$\begin{array}{l}\text { Soil phosphorus } \\
\text { storage }\end{array}$} & \multirow[t]{3}{*}{$B_{\mathrm{TP}}$} \\
\hline & & & & \multirow[t]{2}{*}{ Soil } & \multirow[t]{2}{*}{ Grain } & \multirow[t]{2}{*}{ Straw } & & & \\
\hline & $\mathrm{g} \mathrm{cm}^{-3}$ & $\mathrm{kgPha}^{-1}$ & & & & & & & \\
\hline \multicolumn{10}{|c|}{ 2016.06-2017.06 } \\
\hline NTJ & 1.215 & $2400.6 \pm 4$ & 44 & $2410.7 \pm 22 a$ & $14.96 \pm 0.4 a$ & $8.70 \pm 0.7 a b$ & $10.22 \pm 1.8 \mathrm{c}$ & $2413.2 \pm 4.2 \mathrm{a}$ & $7.78 \pm 2.1 b$ \\
\hline NTG & & & & $2405.8 \pm 14 a b$ & $14.99 \pm 0.5 \mathrm{ab}$ & $10.12 \pm 0.6 a$ & $13.65 \pm 0.4 b$ & $2408.3 \pm 5.1 \mathrm{a}$ & $11.21 \pm 2.6 \mathrm{ab}$ \\
\hline CTJ & & & & $2406.3 \pm 19 a b$ & $15.37 \pm 0.6 a$ & $7.92 \pm 0.9 b$ & $15.00 \pm 2.3 b$ & $2409.2 \pm 4.3 a$ & $12.11 \pm 3.5 \mathrm{a}$ \\
\hline CTG & & & & $2401.4 \pm 8 b$ & $14.20 \pm 0.2 b$ & $8.75 \pm 0.6 a b$ & $20.22 \pm 1.9 a$ & $2403.9 \pm 7.5 a$ & $17.78 \pm 3.2 \mathrm{a}$ \\
\hline \multicolumn{10}{|c|}{ 2017.06-2018.06 } \\
\hline NTJ & 1.221 & $2413.2 \pm 4.2 \mathrm{a}$ & 44 & $2427.7 \pm 6 a$ & $15.76 \pm 0.2 \mathrm{a}$ & $9.00 \pm 0.4 a b$ & $4.71 \pm 0.3 c$ & $2428.5 \pm 1.5 \mathrm{a}$ & $3.83 \pm 0.5 b$ \\
\hline NTG & 1.222 & $2408.3 \pm 5.1 a$ & & $2420.7 \pm 11 a b$ & $15.63 \pm 0.3 a b$ & $10.58 \pm 1.0 \mathrm{a}$ & $5.38 \pm 1.3 \mathrm{bc}$ & $2422.1 \pm 2.4 b$ & $4.01 \pm 0.7 b$ \\
\hline CTJ & 1.219 & $2409.2 \pm 4.3 \mathrm{a}$ & & $2417.6 \pm 12 \mathrm{ab}$ & $15.99 \pm 0.2 \mathrm{a}$ & $8.37 \pm 1.3 b$ & $11.20 \pm 1.5 b$ & $2421.0 \pm 2.2 b$ & $7.89 \pm 1.3 a$ \\
\hline CTG & 1.220 & $2403.9 \pm 7.5 a$ & & $2410.4 \pm 9 b$ & $14.83 \pm 0.3 b$ & $9.17 \pm 0.8 \mathrm{ab}$ & $13.52 \pm 0.8 \mathrm{a}$ & $2412.0 \pm 3.7 c$ & $11.85 \pm 1.6 \mathrm{a}$ \\
\hline
\end{tabular}

NTJ, NTG, CTJ, CTG indicate no-till/japonica rice, no-till/glutinous rice, conventional tillage/japonica rice, conventional tillage/glutinous rice, respectively. Different lowercase letters in each column indicate significant differences set at $p=0.05$ level. End of rice season: October 2016 and October 2017 . End of winter fallow season: June 2017 and June 2018. $B_{\mathrm{Rp}}$ : environmental loss of phosphorus in rice season; $B_{\mathrm{TP}}$ : annual environmental loss of phosphorus

Table 6 Comparison of economic benefits of different tillage treatments

\begin{tabular}{|c|c|c|c|c|c|c|c|}
\hline \multirow[t]{2}{*}{ Treatment } & \multirow[t]{2}{*}{ Yield $\left(\mathrm{kg} \mathrm{ha}^{-1}\right)$} & \multirow{2}{*}{$\begin{array}{l}\text { Gross income } \\
\left(\text { USD ha }^{-1}\right)\end{array}$} & \multicolumn{2}{|c|}{ Production costs } & \multirow{2}{*}{$\begin{array}{l}\text { Net income } \\
(\text { USD ha } \\
\text { (1) }\end{array}$} & \multirow[t]{2}{*}{ Relative value (\%) } & \multirow[t]{2}{*}{ Benefit: cost } \\
\hline & & & $\begin{array}{l}\text { Tillage costs } \\
\left(\text { USD ha }{ }^{-1} \text { ) }\right.\end{array}$ & $\begin{array}{l}\text { Other costs } \\
\left(\text { USD ha } a^{-1}\right)\end{array}$ & & & \\
\hline NTJ & 8483 & 3228.63 & 0 & 504.58 & 2724.25 & 112.06 & 6.40 \\
\hline NTG & 7613 & 3183.00 & 0 & 504.58 & 2678.51 & 110.18 & 6.31 \\
\hline CTJ & 8383 & 3190.57 & 216.25 & 504.58 & 2469.94 & 101.60 & 4.43 \\
\hline CTG & 7538 & 3151.87 & 216.25 & 504.58 & 2431.03 & 100 & 4.37 \\
\hline
\end{tabular}

NTJ, NTG, CTJ, CTG indicate no-till/japonica rice planting, no-till/glutinous rice planting, conventional tillage/japonica rice planting, conventional tillage/glutinous rice planting, respectively. Yield: 2-year average drying yield; the price of japonica rice is calculated in $0.3806 \mathrm{USD}$ per $\mathrm{kg}$, the price of glutinous rice is calculated in 0.4181 USD per kg; other costs include the cost of fertilizer, seeds, etc.; net income = gross income - production costs

Conversely, conventional tillage methods break up soil aggregates and reduce the stability of aggregates [42, 43]. Therefore, the soil $\mathrm{N}$ and $\mathrm{P}$ content of rice fields under no-till management were higher. Caron et al. [44] reported that the porosity index in soil under no-till management was three times that of conventional tillage. The increase of large pores in the vertical direction in no-till soil could enhance water permeability in the soil profile. Under the conditions of no-till management with straw mulching, the rice root system development was better, which improved the utilization of rice field water and soil nutrients, making it easier for grains to obtain nutrients, thereby increasing yield [45-47]. However, the effect of no-till management on $\mathrm{N}$ and $\mathrm{P}$ accumulation in grain and straw was small, which could have possibly occurred because no-till and straw mulching reduced the soil nutrient output in most non-irrigated areas. The contents of soil total $\mathrm{N}$ and total $\mathrm{P}$ during the rice season increased more than that in the fallow season, and the stocks of $\mathrm{N}$ and $\mathrm{P}$ were also higher. The annual environmental losses during the planting season for 2 consecutive years were less than those during the rice season, mainly because of the effects of fertilization during the rice season and the return of straw to the field during the fallow season. Although rice straw residues contained some $\mathrm{N}$ and $\mathrm{P}$, other researchers have pointed out that it takes time for straw mulching to release nutrients into the soil [47]. Therefore, there were lower environmental losses during the planting season because the soil during the rice season could acquire more nutrients through fertilization and straw mulching [48].

The results of the 2-year experiment showed that the NTJ treatment had the best effect on $\mathrm{N}$ and $\mathrm{P}$ emission reduction in rice fields, whereas the CTG treatment had the lowest ability to reduce $\mathrm{N}$ and $\mathrm{P}$ emission from the rice fields. This was mainly because the losses of $\mathrm{N}$ and $\mathrm{P}$ from rice fields were closely related to tillage methods, rice yield, fertilizer application, rainfall, and other factors. With the growth of rice, the amount of $\mathrm{N}$ and $\mathrm{P}$ in the soil increased, indicating that both $\mathrm{N}$ and $\mathrm{P}$ in the soil were 
effectively fixed [11], which possibly occurred because the no-till with straw mulching practice improved the physical and chemical properties of the soil (increased soil porosity, increase soil surface roughness, etc.), and affected the formation and path of runoff, thereby reducing surface runoff and nutrient loss [49-51].

From the perspective of economic benefits, the NTJ method had the highest production-to-investment ratio, and different tillage methods (no-till/conventional tillage) had a relatively large impact on the production costs. The production cost of the no-till treatment was lower than that of conventional tillage, and the yield of the notill treatment of rice was slightly higher than that of the conventional tillage, indicating that no-till contributed to the increased economic benefits $[35,52]$.

One important issue is that although we did not consider the effect of rice residue retention on the $\mathrm{N}$ and $P$ balance, it can still be shown that the no-till practice could reduce soil nutrient loss while maintaining slightly higher yield relative to conventional tillage, and the japonica rice increase grain yield more significant than another variety, thus, the NTJ treatment increasing environmental benefits. In addition, compared with the conventional tillage, no-till reduced the production costs (such as energy input of fuel consumption and machine). The comprehensive analysis showed that the no-till/ japonica rice (Xiushui-134) contributed to the reduction of $\mathrm{N}$ and $\mathrm{P}$ losses in paddy fields and the improvement of grain yield, which is worthy of promotion.

\section{Conclusion}

Our study found that the no-till practice was able to maintain more soil $\mathrm{N}$ and $\mathrm{P}$ nutrients than conventional tillage, and this advantage was more significant when planting japonica rice. In addition, the no-till method was conducive to the $\mathrm{N}$ and $\mathrm{P}$ uptake by rice, and glutinous rice in the rice fields under the no-till treatment effectively increased $\mathrm{N}$ and $\mathrm{P}$ content in straw and grain, but no-till had no significant effect on the increase in rice yield. However, rice varieties were significantly correlated with rice yield, and japonica rice improved rice grain yield. The NTJ treatment reduced the environmental losses of $\mathrm{N}$ and $\mathrm{P}$ in rice fields. Herein, we recommend the NTJ treatment to improve the nutrient balance.

\footnotetext{
Abbreviations

NTJ: No-till/japonica rice planting; NTG: No-till/glutinous rice planting; CTJ: Conventional tillage/japonica rice planting; CTG: Conventional tillage/glutinous rice planting; $R_{1}$ : The first rice season: (June 2016-October 2016); $R_{2}$ : The second rice season (June 2017-October 2017); $R_{1 \mathrm{E}}$ : The end of the first rice season; $R_{2}$ : The end of the second rice season; $F_{1}$ : The first fallow season (October 2016-June 2017); $F_{2}$ : The second fallow season (October 2017-June 2018); $F_{1 E}$ : The end of the first fallow season; $F_{2 E}$ : The end of the second fallow season; $T_{1}$ : The first planting season (June 2016-June 2017); $T_{2}$ : The second
}

fallow season (June 2017-June 2018); $T_{1 \mathrm{E}}$ : The end of the first planting season; $T_{2 E}$ : The end of the second planting season; $C E C$ : Cation exchange capacity.

\section{Acknowledgements}

We highly appreciate everyone who contributed to accomplish this study.

\section{Authors' contributions}

$X L$ designed the experiment, $X L$ and $Y C$ performed the sampling and analysis, $J Y$ accomplished manuscript. All authors were involved in revising the manuscript. All authors read and approved the final manuscript.

\section{Funding}

Fund for this research have been provided by the National Key Science and Technology Project: Water Pollution Control and Treatment (2018ZX07208009), National Natural Science Foundation of China $(41671300,41522108)$, National Key Research and Development Program of China (2017YFD0800103).

Availability of data and materials

All data sources are provided in "Materials and methods", as well as in "Results".

Ethics approval and consent to participate

Not applicable.

Consent for publication

Not applicable.

\section{Competing interests}

The authors declare that they have no competing interests.

\section{Author details}

${ }^{1}$ College of Environmental and Resource Sciences, Zhejiang University, Hangzhou 310058 , China. ${ }^{2}$ Key Laboratory of Environmental Remediation and Ecological Health, Ministry of Education, Zhejiang University, Hangzhou 310058, China. ${ }^{3}$ Institute of Environment, Resource, Soil and Fertilizer, Zhejiang Academy of Agricultural Sciences, Hangzhou 310021, China.

Received: 29 December 2019 Accepted: 9 February 2020

Published online: 26 February 2020

References

1. FAO (2011) Save and grow: a policymaker's guide to the sustainable intensification of smallholder crop production. FAO, Rome, pp 1-37

2. Skaalsveen K, Ingram J, Clarke LE (2019) The effect of no-till farming on the soil functions of water purification and retention in north-western Europe: a literature review. Soil Tillage Res 189:98-109. https://doi. org/10.1016/j.still.2019.01.004

3. Sanaullah M, Usman M, Wakeel A, Cheema SA, Ashraf I, Farooq M (2020) Terrestrial ecosystem functioning affected by agricultural management systems: a review. Soil Tillage Res 196:104464. https://doi.org/10.1016/j. still.2019.104464

4. Barreto RC, Madari BE, Maddock JEL, Machado PLOA, Torres E, Franchini J, Costa AR (2009) The impact of soil management on aggregation, carbon stabilization and carbon loss as CO2 in the surface layer of a Rhodic Ferralsol in Southern Brazil. Agric Ecosyst Environ 132:243-251. https://doi. org/10.1016/j.agee.2009.04.008

5. Zhao C, Chai Q, Cao W, Whalen JK, Zhao L, Cai L (2019) No-tillage reduces competition and enhances compensatory growth of maize (Zea mays L.) intercropped with pea (Pisum sativum L.). Field Crop Res 243:107611. https://doi.org/10.1016/j.fcr.2019.107611

6. Vogeler I, Rogasik J, Funder U, Panten K, Schnug E (2009) Effect of tillage systems and P-fertilization on soil physical and chemical properties, crop yield and nutrient uptake. Soil Tillage Res 103:137-143. https://doi. org/10.1016/j.still.2008.10.004

7. Page KL, Dang YP, Dalal RC, Reeves S, Thomas G, Wang W, Thompson JP (2019) Changes in soil water storage with no-tillage and crop residue retention on a Vertisol: impact on productivity and profitability over a 50 year period. Soil Tillage Res 194:104319. https://doi.org/10.1016/j.still 2019.104319 
8. Franchini JC, Debiasi H, Balbinot Junior AA, Tonon BC, Farias JRB, de Oliveira MCN, Torres E (2012) Evolution of crop yields in different tillage and cropping systems over two decades in southern Brazil. Field Crop Res 137:178-185. https://doi.org/10.1016/j.fcr.2012.09.003

9. Niu Y, Cai Y, Chen Z, Luo J, Di HJ, Yu H, Zhu A, Ding W (2019) No-tillage did not increase organic carbon storage but stimulated N2O emissions in an intensively cultivated sandy loam soil: a negative climate effect. Soil Tillage Res 195:104419. https://doi.org/10.1016/j.still.2019.104419

10. Borges R, Mallarino AP (2000) Grain yield, early growth, and nutrient uptake of no-till soybean as affected by phosphorus and potassium placement. Agron J 92:380-388. https://doi.org/10.2134/agronj2000 922380x

11. Page K, Dang Y, Dalal R (2013) Impacts of conservation tillage on soil quality, including soil-borne crop diseases, with a focus on semi-arid grain cropping systems. Aust Plant Pathol 42:363-377. https://doi.org/10.1007/ s13313-013-0198-y

12. Martínez I, Chervet A, Weisskopf P, Sturny WG, Etana A, Stettler M, Forkman J, Keller T (2016) Two decades of no-till in the Oberacker long-term field experiment: part I. Crop yield, soil organic carbon and nutrient distribution in the soil profile. Soil Tillage Res 163:141-151. https://doi. org/10.1016/j.still.2016.05.021

13. Messiga AJ, Ziadi N, Morel C, Grant C, Tremblay G, Lamarre G, Parent LE (2012) Long term impact of tillage practices and biennial $P$ and $N$ fertilization on maize and soybean yields and soil P status. F Crop Res 133:10-22. https://doi.org/10.1016/j.fcr.2012.03.009

14. Stackpoole SM, Stets EG, Sprague LA (2019) Variable impacts of contemporary versus legacy agricultural phosphorus on US river water quality. Proc Natl Acad Sci USA 116:20562-20567. https://doi.org/10.1073/ pnas.1903226116

15. Chen MP, Chen JN (2007) Inventory of regional surface nutrient balance and policy recommendations in China. Huanjing Kexue/Environ Sci 28:1305-1310 (in Chinese)

16. Li J, Du Z, Yan C, Gao W (2018) Evolution of cropland nitrogen and phosphorus apparent balance in plateau region: a case study of Kunming City. Acta Sci Circumst 38:4823-4830 (in Chinese)

17. Hanrahan BR, King KW, Williams MR, Duncan EW, Pease LA, LaBarge GA (2019) Nutrient balances influence hydrologic losses of nitrogen and phosphorus across agricultural fields in northwestern Ohio. Nutr Cycl Agroecosyst 113:231-245. https://doi.org/10.1007/s10705-019-09981-4

18. Wang J, Xiao X, Qin Y, Dong J, Zhang G, Kou W, Jin C, Zhou Y, Zhang Y (2015) Mapping paddy rice planting area in wheat-rice double-cropped areas through integration of Landsat-8 OLI, MODIS, and PALSAR images. Sci Rep 5:10088. https://doi.org/10.1038/srep10088

19. Suriyagoda L, Sirisena D, Kekulandara D, Bandaranayake P, Samarasinghe G, Wissuwa M (2020) Biomass and nutrient accumulation rates of rice cultivars differing in their growth duration when grown in fertile and low-fertile soils. J Plant Nutr 43:251-269. https://doi.org/10.1080/01904 167.2019 .1676903

20. Fan J, Zhang Y, Turner D, Duan Y, Wang D, Shen Q (2010) Root physiological and morphological characteristics of two rice cultivars with different nitrogen-use efficiency. Pedosphere 20:446-455. https://doi.org/10.1016/ S1002-0160(10)60034-3

21. Wei H, Hu L, Zhu Y, Zhu Ying, Xu D, Zheng L, Chen Z, Hu Y, Cui P, Guo B, Dai Q, Zhang H (2018) Different characteristics of nutrient absorption and utilization between inbred japonica super rice and inter-sub-specific hybrid super rice. Field Crop Res 218:88-96. https://doi.org/10.1016/j. fcr.2018.01.012

22. Zhang $Q$, Wang $G$ (2006) Yield of inbred rice and hybrid rice and soil nutrient balance under long-term fertilization. Plant Nutr Fertil Sci 12:340-345 (in Chinese)

23. Liang X, Chen Y, Nie Z, Ye Y, Liu J, Tian G, Wang G, Tuong TP (2013) Mitigation of nutrient losses via surface runoff from rice cropping systems with alternate wetting and drying irrigation and site-specific nutrient management practices. Environ Sci Pollut Res 20:6980-6991. https://doi. org/10.1007/s11356-012-1391-1

24. Sumner ME, Miller WP, Sparks DL, Page AL, Helmke PA, Loeppert RH, Soltanpour PN, Tabatabai MA, Johnston CT (1996) Cation exchange capacity and exchange coefficients. Open Chem Biomed Method. pp 146

25. Murphy J, Riley JP (1962) A modified single solution method for the determination of phosphate in natural waters. Anal Chim Acta 27:31-36. https://doi.org/10.1016/S0003-2670(00)88444-5
26. Li Z, Zheng L, Lu L, Li L (2014) Improvement in the $\mathrm{H}_{2} \mathrm{SO}_{4}-\mathrm{H}_{2} \mathrm{O}_{2}$ digestion method for determining plant total nitrogen. Chin Agric Sci Bull 30:159-162 (in Chinese)

27. Chapuis Lardy L, Brossard M, Lopes Assad ML, Laurent JY (2002) Carbon and phosphorus stocks of clayey Ferralsols in Cerrado native and agroecosystems, Brazil. Agric Ecosyst Environ 92:147-158. https://doi. org/10.1016/S0167-8809(01)00303-6

28. Van den Putte A, Govers G, Diels J, Gillijns K, Demuzere M (2010) Assessing the effect of soil tillage on crop growth: a meta-regression analysis on European crop yields under conservation agriculture. Eur J Agron 33:231-241. https://doi.org/10.1016/j.eja.2010.05.008

29. De Vita P, Di Paolo E, Fecondo G, Di Fonzo N, Pisante M (2007) No-tillage and conventional tillage effects on durum wheat yield, grain quality and soil moisture content in southern Italy. Soil Tillage Res 92:69-78. https:// doi.org/10.1016/j.still.2006.01.012

30. Pittelkow CM, Liang X, Linquist BA, Van Groenigen LJ, Lee J, Lundy ME, Van Gestel N, Six J, Venterea RT, Van Kessel C (2015) Productivity limits and potentials of the principles of conservation agriculture. Nature 517:365-368. https://doi.org/10.1038/nature13809

31. Liang X, Zhang H, He M, Yuan J, Xu L, Tian G (2016) No-tillage effects on grain yield, N use efficiency, and nutrient runoff losses in paddy fields. Environ Sci Pollut Res 23:21451-21459. https://doi.org/10.1007/s1135 6-016-7338-1

32. Qin J, Hu F, Li D, Li H, Lu J, Yu R (2010) The effect of mulching, tillage and rotation on yield in non-flooded compared with flooded rice production. J Agron Crop Sci 196:397-406. https://doi.org/10.1111/j.1439037X.2010.00430.x

33. Moe K, Moh SM, Htwe AZ, Kajihara Y, Yamakawa T (2019) Effects of integrated organic and inorganic fertilizers on yield and growth parameters of rice varieties. Rice Sci 26:309-318. https://doi.org/10.1016/j. rsci.2019.08.005

34. Jiang X, Xie D (2009) Combining ridge with no-tillage in lowland ricebased cropping system: long-term effect on soil and rice yield. Pedosphere 19:515-522. https://doi.org/10.1016/S1002-0160(09)60144-2

35. Guo Y, Yin W, Hu F, Fan Z, Fan H, Zhao C, Yu A, Chai Q, Coulter JA (2019) Reduced irrigation and nitrogen coupled with no-tillage and plastic mulching increase wheat yield in maize-wheat rotation in an arid region. Field Crop Res 243:107615. https://doi.org/10.1016/j.fcr.2019.107615

36. Dordas C (2009) Dry matter, nitrogen and phosphorus accumulation, partitioning and remobilization as affected by $\mathrm{N}$ and $\mathrm{P}$ fertilization and source-sink relations. Eur J Agron 30:129-139. https://doi.org/10.1016/j. eja.2008.09.001

37. Papakosta DK, Gagianas AA (1991) Nitrogen and dry matter accumulation, remobilization, and losses for mediterranean wheat during grain filling. Agron J 83:864. https://doi.org/10.2134/agronj1991.0002196200 $8300050018 x$

38. Ma L, Kong F, Wang Z, Luo Y, Lv X, Zhou Z, Meng Y (2019) Growth and yield of cotton as affected by different straw returning modes with an equivalent carbon input. Field Crop Res 243:107616. https://doi. org/10.1016/j.fcr.2019.107616

39. Xavier CV, Moitinho MR, De Bortoli Teixeira D, de Araújo André, Santos G, de Andrade Barbosa M, Bastos Pereira Milori DM, Rigobelo E, Corá JE, La Scala Júnior N (2019) Crop rotation and succession in a no-tillage system: implications for $\mathrm{CO}_{2}$ emission and soil attributes. J Environ Manage 245:8-15. https://doi.org/10.1016/j.jenvman.2019.05.053

40. Yadav GS, Das A, Lal R, Babu S, Datta M, Meena RS, Patil SB, Singh R (2019) Impact of no-till and mulching on soil carbon sequestration under rice (Oryza sativa L.)-rapeseed (Brassica campestris L. var. rapeseed) cropping system in hilly agro-ecosystem of the Eastern Himalayas, India. Agric Ecosyst Environ 275:81-92. https://doi.org/10.1016/j.agee.2019.02.001

41. Chen Z, Wang H, Liu X, Zhao X, Lu D, Zhou J, Li C (2017) Changes in soil microbial community and organic carbon fractions under short-term straw return in a rice-wheat cropping system. Soil Tillage Res 165:121127. https://doi.org/10.1016/.still.2016.07.018

42. Jilling A, Kane D, Williams A, Yannarell AC, Davis A, Jordan NR, Koide RT, Mortensen DA, Smith RG, Snapp SS, Spokas KA, Stuart Grandy A (2020) Rapid and distinct responses of particulate and mineral-associated organic nitrogen to conservation tillage and cover crops. Geoderma 359:114001. https://doi.org/10.1016/j.geoderma.2019.114001

43. Wang H, Wang S, Wang R, Zhang Y, Wang X, Li J (2019) Direct and indirect linkages between soil aggregates and soil bacterial communities under 
tillage methods. Geoderma 354:113879. https://doi.org/10.1016/j.geode rma.2019.113879

44. Caron J, Kay BD, Perfect E (1992) Short-term decrease in soil structural stability following bromegrass establishment on a clay loam soil. Plant Soil 145:121-130. https://doi.org/10.1007/BF00009548

45. Qin R, Stamp P, Richner W (2004) Impact of tillage on root systems of winter wheat. Agron J 96:1523-1530. https://doi.org/10.2134/agronj2004 .1523

46. Chakraborty D, Nagarajan S, Aggarwal P, Gupta VK, Tomar RK, Garg RN, Sahoo RN, Sarkar A, Chopra UK, Sarma KSS, Kalra N (2008) Effect of mulching on soil and plant water status, and the growth and yield of wheat (Triticum aestivum L.) in a semi-arid environment. Agric Water Manag 95:1323-1334. https://doi.org/10.1016/j.agwat.2008.06.001

47. Yan F, Sun Y, Hui X, Jiang M, Xiang K, Wu Y, Zhang Q, Tang Y, Yang Z, Sun $Y$, Jun M (2019) The effect of straw mulch on nitrogen, phosphorus and potassium uptake and use in hybrid rice. Paddy Water Environ 17:23-33. https://doi.org/10.1007/s10333-018-0680-9

48. Ju J, Cai Y, Zuo W, Hai-Tao Z, Yang H, Mao W, Yu-Hua S, Ke F (2019) Effects of nitrogen management on soil nitrogen content and rice grain yield in double cropping rice production area with continuous full amount of straw returning. Commun Soil Sci Plant Anal 50:2655-2668. https://doi. org/10.1080/00103624.2019.1671447
49. Sun Y, Zeng Y, Shi Q, Pan X, Huang S (2015) No-tillage controls on runoff: a meta-analysis. Soil Tillage Res 153:1-6. https://doi.org/10.1016/j.still 2015.04.007

50. Jordán A, Zavala LM, Gil J (2010) Effects of mulching on soil physical properties and runoff under semi-arid conditions in southern Spain. CATENA 81:77-85. https://doi.org/10.1016/j.catena.2010.01.007

51. Wang J, Lü G, Guo X, Wang Y, Ding S, Wang D (2015) Conservation tillage and optimized fertilization reduce winter runoff losses of nitrogen and phosphorus from farmland in the Chaohu Lake region, China. Nutr Cycl Agroecosyst 101:93-106. https://doi.org/10.1007/s10705-014-9664-3

52. Singh A, Phogat VK, Dahiya R, Batra SD (2014) Impact of long-term zero till wheat on soil physical properties and wheat productivity under rice-wheat cropping system. Soil Tillage Res 140:98-105. https://doi. org/10.1016/j.still.2014.03.002

\section{Publisher's Note}

Springer Nature remains neutral with regard to jurisdictional claims in published maps and institutional affiliations.

\section{Submit your manuscript to a SpringerOpen ${ }^{\circ}$ journal and benefit from:}

- Convenient online submission

- Rigorous peer review

- Open access: articles freely available online

- High visibility within the field

- Retaining the copyright to your article

Submit your next manuscript at $\boldsymbol{\nabla}$ springeropen.com 